40. Strittmatter WJ, Saunders AM, Schmechel D, et al. Apolipoprotein E: high avidity binding to beta-amyloid and increased frequency of type 4 allele in late-onset familial Alzheimer disease. Proc Natl Acad Sci USA 1993;90:1977-1981.

41. Weisgraber KH, Mahley RW. Human apolipoprotein E: the Alzheimer's disease connection. FASEB J 1996;10:1485-1494.

42. Jarvik GP, Wijsman EM, Kukull WA, Schellenberg GD, Yu C, Larson EB. Interaction of apolipoprotein $\mathrm{E}$ genotype, total cholesterol level, age, and sex in prediction of Alzheimer's disease: a case-control study. Neurology 1995;45:1092-1096.

43. Sing CF, Davignon J. Role of the apolipoprotein E polymorphism in the determining normal plasma lipid and lipoprotein variation. Am J Hum Genet 1985;37:268-285.

44. Michikawa M, Fan QW, Isobe I, Yanagisawa K. Apolipoprotein $\mathrm{E}$ exhibits isoform-specific promotion of lipid efflux from astrocytes and neurons in culture. J Neurochem 2000;74:1008-1016.

\title{
Neuro/mages
}
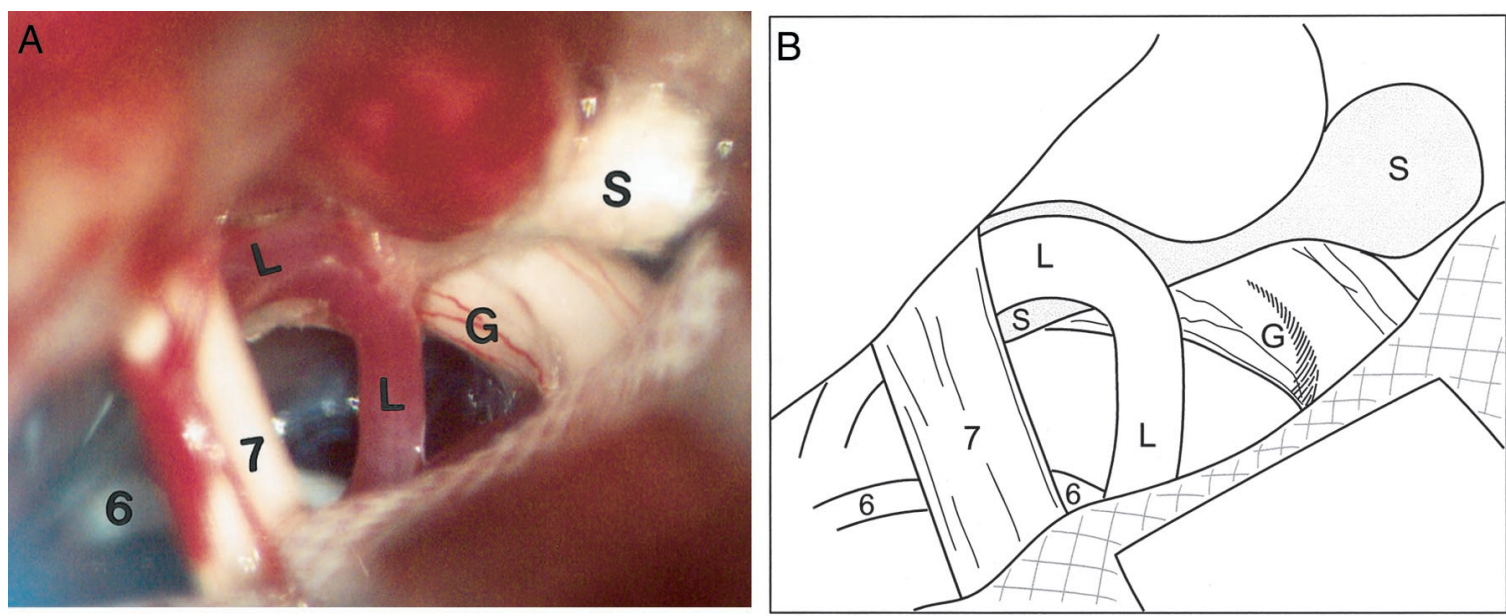

Figure. Posterior view of left cerebellopontine angle showing loop $(L)$ of the anterior inferior cerebellar artery separated from groove $(G)$ in the trigeminal nerve by a Teflon sponge (Boston Scientific, Medox Medical Industries, Oakland, NJ) (S). Note the seventh and eighth nerve complex (7) (superior and inferior vestibular nerves hiding facial and acoustic nerves) and sixth nerve (6).

\section{Microvascular decompression for trigeminal neuralgia}

Rafael Allende, MD, Sandeep Teja, $M D$,

Cargill H. Alleyne, Jr., MD, Rochester, NY

A 58-year-old woman presented with sharp, lancinating pain in the V2 distribution unresponsive to carbamazepine. Her neurologic examination and an MRI were unremarkable. The patient underwent a posterior fossa craniectomy for microvascular decompression (MVD) where a loop of the anterior inferior cerebellar artery was noted to compress the trigeminal nerve. Her symptoms resolved postoperatively. Trigeminal neuralgia most commonly affects the V2 and V3 branches. Microvascular decompression has an initial success rate of 85 to $95 \%$ with a recurrence rate of $20 \%$ and $30 \%$, at 6 and 10 years. ${ }^{1,2}$ There is no sensory loss associated with MVD.

1. Janetta PJ. Trigeminal neuralgia: treatment by microvascular decompression. In: Wilkins RH, Rengachary SS, eds. Neurosurgery, vol III. New York: McGraw-Hill, 1996:3961-3968.

2. Barker FG, Jannetta PJ, Bissonette DJ, Larkins MV, Jho HD. The long-term outcome of microvascular decompression for trigeminal neuralgia. N Engl J Med 1996;334:1077-1083. 


\section{Neurology}

\section{Microvascular decompression for trigeminal neuralgia}

Rafael Allende, Sandeep Teja and Cargill H. Alleyne, Jr.

Neurology 2001;57;1093

DOI 10.1212/WNL.57.6.1093

This information is current as of September 25, 2001

\section{Updated Information \& Services}

\section{References}

Subspecialty Collections

Permissions \& Licensing

Reprints

\section{including high resolution figures, can be found at:} http://n.neurology.org/content/57/6/1093.full

This article cites 1 articles, 0 of which you can access for free at: http://n.neurology.org/content/57/6/1093.full\#ref-list-1

This article, along with others on similar topics, appears in the following collection(s):

\section{Trigeminal neuralgia}

http://n.neurology.org/cgi/collection/trigeminal_neuralgia

Information about reproducing this article in parts (figures,tables) or in its entirety can be found online at:

http://www.neurology.org/about/about_the_journal\#permissions

Information about ordering reprints can be found online:

http://n.neurology.org/subscribers/advertise

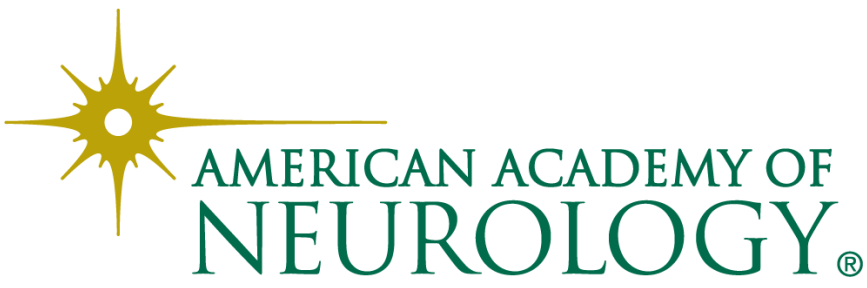

